\title{
GC/MS による高脂肪食品中ラクトン類の簡易定量
}

\author{
松浦 弘明 ${ }^{1}$, 塩 田 誠*1
}

\section{1 緒言}

ラクトン類は, フルーティーで甘い風味を特徴とする香 気成分である，バターやチーズ，発酵乳などの乳製品に広 く存在する, 乳の風味を形成する重要な香気成分であり, その含有量や組成比の違いにより食品の風味を特徴付けて いる. ラクトン類は乳脂肪感を与える主要成分であること から，バター様の乳風味を有するマーガリン類への添加が 行われている ${ }^{1)}$. 乳中のラクトン類としては, 主に 5 員環 の $\gamma$-ラクトンと 6 員環の $\delta$-ラクトン類が存在し, その中で は $\delta$-ドデカラクトンや $\delta$-デカラクトンが代表的である. そ のほかにも鎖長構造が異なる多様なラクトン類が存在し, その組成の違いが各乳製品の風味の個性に関連してい る2) 4). また，ラクトンは乳製品のみならず，果物やワイ ンなどの発酵食品の重要な風味成分でもあり, 幅広い食品 の風味を決定する重要な因子とされている

食品中の香気成分は, ヘッドスペース法 (HS 法), 水蒸 気蒸留法などにより, 香気成分を抽出/濃縮したのち, ガ スクロマトグラフィー/質量分析法 (GC/MS) で測定する ことができる ${ }^{8) 9}$. 最近では, 試料を保持した容器中のへッ ドスペース中の香気成分を直接 GC に導入する方法や固相 マイクロ抽出（SPME）法やテナックス法など, ヘッドス ペース中の香気成分を樹脂に吸着させたのち，GCに導入 する方法など，多様な方法が利用される。しかし，いずれ の方法も食品のマトリクスから気相中に移行したものを濃 縮し測定に供するため, 香気成分と試料中のマトリクスと の相互作用や気液分配などの様々な要因により, 食品中の 濃度や組成が分析結果に直接反映されないという問題があ $ろ^{10)}$. 溶郕抽出法としては, Solvent-assisted flavor evaporation（SAFE）装置を用いた測定が広く行われるが，油脂含 量の高い試料からの香気成分の抽出では, 親油性の高い揮 発性物質を油脂から溶剤へ十分に移行させる必要があるた め, 長時間の抽出時間を要し, 再現性にも課題がある ${ }^{1112)}$. 加えて, 抽出作業時の溶出や転溶に用いるジエチルエーテ ルやジクロロメタンなどの溶剤を減圧濃縮により留去する

\footnotetext{
*E-mail : m-shiota@mtf.biglobe.ne.jp

1 雪印メグミルク株式会社ミルクサイエンス研究所 : 350-1165 埼玉県川越市南台 1-1-2
}

際に，測定対象とする揮発性物質も逸散される可能性もあ る. 水蒸気蒸留法では, 抽出工程中に試料に加えられる加 熱により生成するラクトン類の存在が無視できないため, 定量性に問題がある ${ }^{13)}$. ラクトン類の定量については, 下 田ら ${ }^{14)}$ は低密度ポリエチレン膜を使用したパウチ法を用い た方法を報告しているが, 添加回収率が $10 \%$ と低く課題 があると考えられる。 このように既報のラクトン類の定量 值には，個々の化合物の回収率に起因する信頼性に問題が あると考えられる，一方で，品質管理及び工程管理の観点 から, 乳製品の香気として重要なラクトン類をより精度高 く，簡便に定量する分析技術が必要とされている $\left.{ }^{15} 16\right)$.

本研究の目的は, 高脂肪食品中のラクトン類を簡便かつ 高精度に定量する方法を開発することである。へキサン溶 解物を直接 GCにてて測定する（直接導入法）ことで, 従来 のヘッドスペース法での課題である気相への移行度や溶郕 抽出法に扔ける分配率の問題がなく, 試料を溶剂に希釈溶 解するだけの簡便な前処理で測定が可能である．直接導入 法では, トリグリセリド（TG）等の高沸点成分が GC 測定 の妨害成分となるが，本法では，無極性で膜厚が薄い（0.1 $\mu \mathrm{m}$ ）高温分析用のキャピラリーカラムを用い, ラクトン類 の分離定量後の昇温により TG をカラムから排出すること で問題を解決した，本報告では，ラクトン類の定量性に関 する検討結果と市販の油脂製品の分析への応用結果を報告 する.

$$
2 \text { 実験 }
$$

\section{$2 \cdot 1$ 分析装置}

ガスクロマトグラフ/質量分析計 (GC/MS) は島津製作 所製 QP-2010を使用し，オートサンプラーは同社の AOC20i 型を用いた.

\section{$2 \cdot 2$ ラクトン標準混合ヘキサン溶液, 試薬及び市販油 脂製品}

標準溶液に用いたラクトン類としては, $\gamma$-octalactone $(\gamma$-C8)（シグマ・アルドリッチ製)， $\gamma$-nonalactone $(\gamma$-C9 $)$ (東京化成工業製)， $\gamma$-decalactone（ $\gamma$-C10）（和光純薬 工業製), $\gamma$-undecalactone $(\gamma$-C11) (和光純薬工業製), $\gamma$-dodecalactone $(\gamma$-C12)（日本香料薬品製）， $\delta$-hexalactone 
Table 1 Operation conditions for GC/MS

\begin{tabular}{ll}
\hline Instrument & Shimadzu GCMS-QP2010 \\
Column & DB-1 (J\&W), $15 \mathrm{~m} \times 0.25$ (i.d.) $0.1 \mu \mathrm{m}$ (f.t.) \\
Coulmn temp. & $40^{\circ} \mathrm{C}(3 \mathrm{~min}), 4^{\circ} \mathrm{C} \min ^{-1}$ to $170{ }^{\circ} \mathrm{C}, 25^{\circ} \mathrm{C} \mathrm{min}^{-1}$ to $370{ }^{\circ} \mathrm{C}(7 \mathrm{~min})$ \\
linear velocity & $72.1 \mathrm{~cm} \mathrm{~min}{ }^{-1}$ \\
Carrier gas & Helium $49.1 \mathrm{kpa}$ \\
Split & $20: 1$ \\
Ion source & $\mathrm{EI} 1.3 \mathrm{kV}$ \\
Inlet temp. & $370^{\circ} \mathrm{C}$ \\
Detector temp. & $345^{\circ} \mathrm{C}$ \\
Ionization voltage & $70 \mathrm{eV}$ \\
Monitor ion & Qualitative analysis: lactones total ion $m / z 42-500$ \\
& Quantitative analysis: $\gamma$-lactone $m / z 85, \delta$-lactone $m / z 99$, diphenyl $m / z 154$ \\
\hline
\end{tabular}

( $\delta$-C6）（シグマ・アルドリッチ製 $), \delta$-octalactone（ $\delta$-C8） (和光純薬工業製), $\delta$-nonalactone $(\delta$-C9) (和光純薬工業製), $\delta$-decalactone $(\delta$-C10) (東京化成工業製), $\delta$-undecalactone $(\delta$-C11）（和光純薬工業製）， $\delta$-dodecalactone（ $\delta$-C12）（東 京化成工業製), $\delta$-tetradecalactone $(\delta$-C14)（和光純薬工業 製)， $\delta$-hexadecalactone $(\delta$-C16）（和光純薬工業製）を使用 した，それぞれ $100 \mathrm{mg}$ をエタノールで希釈し $10 \mathrm{~mL}$ に定 容した。このエタノール溶液を適時へキサンで希釈混合 し, ラクトン標準混合へキサン溶液とした. 内標準溶液と して, $5000 \mu \mathrm{g} \mathrm{mL}^{-1}$ のジフェニル（Ph2）（和光純薬工業 製）のへキサン溶液を使用した。使用溶剂には, 試薬特級 ヘキサン (和光純薬工業製), 試薬特級エタノール(和光純 薬工業製）を用いた. 測定対象として, 市販油脂食品であ るバター(食塩不使用タイプ), マーガリン類 (マーガリン 及びファットスプレッド), 生クリーム（種類別クリーム） は, 2016 年に埼玉県及び東京都の小売店で購入したものを 試料として用いた。

\section{$2 \cdot 3$ 試料の前処理}

本研究の測定対象試料の油脂食品として, バター, ク リーム及びマーガリン類を選定した. バターは $3.0 \mathrm{~g}$ を使 用し, マーガリン類では香料由来のラクトン類を数 10 $\mu \mathrm{g} \mathrm{g}^{-1}$ 程度と, バターと比較して多量に含むため $1.0 \mathrm{~g}$ を使 用した. 試料を $10 \mathrm{~mL}$ 容量の目盛付きガラス製遠沈管に秤 取し，ヘキサンを加え $10 \mathrm{~mL}$ に定容した. $50{ }^{\circ} \mathrm{C}$ で加温溶 解し, 振とう処理及び超音波処理後に冷却し $2000 \mathrm{rpm}$ で 5 分間遠心分離した. ヘキサン層を無水硫酸ナトリウムで 脱水後 $1.5 \mathrm{~mL}$ のバイアルに $1.0 \mathrm{~mL}$ 分取し, 内標準溶液 0.1 $\mathrm{mL}\left(500 \mu \mathrm{g} \mathrm{mL} \mathrm{m}^{-1}\right.$ に調製した $\mathrm{Ph} 2$ のヘキサン溶液) を添加 混合し GC 測定用試験溶液とした. 油中水型 (W/O) 乳化 食品であるバターやマーガリン類とは異なる, 連続相が水 である水中油型 $(\mathrm{O} / \mathrm{W})$ 乳化食品であるクリームについて は, $3.0 \mathrm{~g}$ の試料に $1 \mathrm{~g}$ の $\mathrm{NaCl}$ を添加したのちにへキサン を加えて定容した。 また，製品中の香料の定量には必要に 応じてエタノールを用いて適時希釈し GC 測定用試験溶液 とした.

\section{$2 \cdot 4 \quad \mathrm{GC} / \mathrm{MS}$ 測定}

ラクトン標準混合ヘキサン溶液をへキサンで希釈し， 1 , 5，10，50，100 $\mu \mathrm{g} \mathrm{mL} \mathrm{m}^{-1}$ に調製した. その $1.0 \mathrm{~mL}$ を試料 の前処理と同様に $1.5 \mathrm{~mL}$ バイアルに分取し, 内標準溶液 を $0.1 \mathrm{~mL}$ 添加し検量線作成用とした. GC/MS の分析条件 を Table 1 に示す. 測定はスキャンモード $m / z 42 \sim 500$ で 実施し, 定量イオンとして, $\gamma$-ラクトンは $m / z 85, \delta$-ラク トンは $m / z 99$ を用いて面積值を求めた. 市販製品分析時 のラクトン類は, 標準試薬のリテンションタイム, 物質の リテンションインデックス情報, MS スペクトルのライブ ラリ（NIST）との一致により同定した.

\section{3 結果と考察}

\section{$3 \cdot 1 \mathrm{GC} / \mathrm{MS}$ による分析条件の検討}

GC カラム選定と測定条件の最適化を目的として, ラク トン混合標準溶液を用いてスキャン検出による分析を実施 した. GCカラムについてはAgilent J \& W 製 DB-1HT, DB-1 及びジーエルサイエンス製 InertCap pure-WAX の 3 製品を用いて比較したところ, いずれのカラムも良好な分 離を示した. しかし, 今回の分析では, GCへの試料導入 時の前処置による TG などの夾雑油脂分の除去を実施しな いため, TG が溶出可能な最高使用温度 $400{ }^{\circ} \mathrm{C}$ の高温分析 用カラム Agilent J \& W 製 DB-1HT を用い, ラクトン類の 分離後, カラム中から昇温により TG を溶出させることと した，温度条件は $40{ }^{\circ} \mathrm{C}$ から昇温を開始し，各ラクトン類 を順次溶出させ, $\delta$-C16 の溶出後にオーブン温度を $370{ }^{\circ} \mathrm{C}$ まで急速に昇温し，TGを溶出した，今回設定した条件で 市販バターを分析したところ, 最も溶出が遅い $\delta$-C16 は 33 分付近に溶出した. また, 50 分までに TGの溶出を完了し た (Fig. 1).

\section{$3 \cdot 2$ 前処理条件の検討}

従来技術による前処理法としては, 溶剂抽出法やへッド スペース法, 蒸留法などが存在するが, 気液相や吸着樹脂 への成分の分配が行われるため, 香気成分の回収率が常に 課題となっていた。 そこで, 今回, 分配を考慮する必要が 

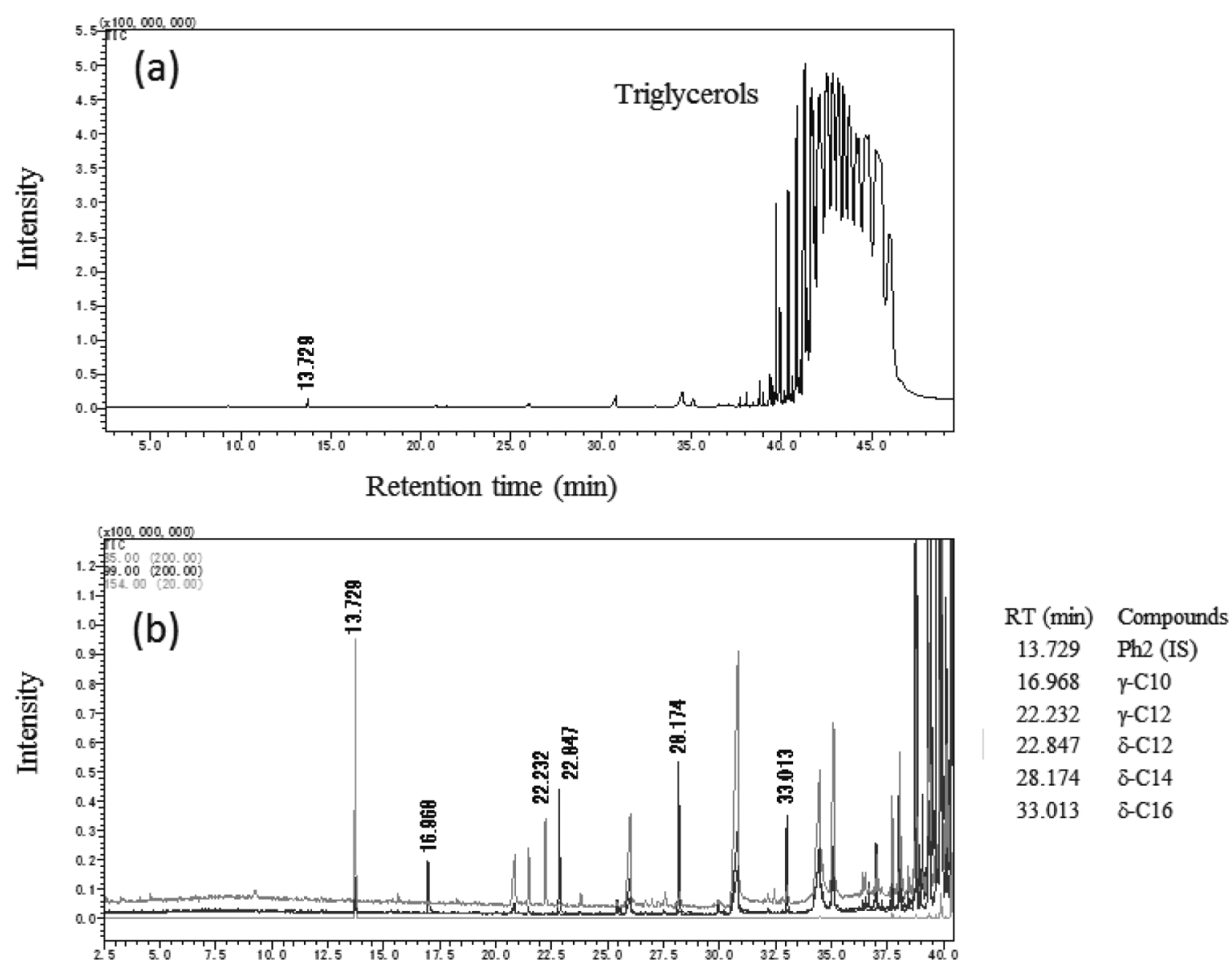

Retention time ( $\mathrm{min})$

Fig. 1 GC/MS chromatogram of butter sample

a, Elution pattern of triglycerides by total ion chromatogram; b, Elution pattern of $\gamma$-lactones $(m / z 85), \delta$-lactones $(m / z 99)$, and biphenyl $(m / z 154)$.

ない，溶剤による直接希釈法を検討した，使用溶剤として は，ジクロロメタンやクロロホルムなど塩素系溶剤は用い ず，毒性が低く油脂の溶解性が高いへキサンを用いた，本 前処理ではラクトン類は親油性が高いため $(\delta$-C10 の分配 係数 $\left.\log P_{\mathrm{OW}}=2.4\right)$, 少量含有する水層部への分配は起こ らないものと考えられるため, 回収率等を考慮することな く定量可能と考えた。 バ夕ーと比較して水分含量が高いク リーム類については，(1)バターと同条件での調製，(2)ク リームにラクトン類のヘキサン層への移行を促すことを目 的として $1.0 \mathrm{~g}$ の $\mathrm{NaCl}$ を添加後にへキサンを用いて定容 して調製した 2 方法を用い, $\mathrm{NaCl}$ の添加の有無の影響を添 加回収試験により調べた.

\section{$3 \cdot 3$ 検量線と標準溶液の繰り返し精度}

Table 1 に示した GC/MS 条件を用いた標準試料のクロ マトグラムを Fig. 2 に示す. 近接する $\delta$-C9 と Ph2 のピー クの分離度は 1.03 であり, 他のピークは完全分離してい た.ここでは, $\gamma$-ラクトンは $m / z 85, \delta$-ラクトンは $m / z 99$
を用いて定量を行った. 1 〜 $100 \mu \mathrm{g} \mathrm{mL} \mathrm{m}^{-1}$ の範囲で濃度を変 化させたラクトン標準溶液を用いて, GC/MS 測定で得ら れた被検物質のピークの面積を, 内標準のピーク面積での 補正を行った值を用いて検量線を作成した，乳製品中に比 較的多く存在する $\delta$-C10 の回帰式は, $y=45.254 x-73825$ $\left(R^{2}=0.9976\right)$ であった。また, $\delta$-C12 の回帰式は, $y=$ $44.807 x-115044 （ R^{2}=0.9952 ）$ であった．両ラクトン類と もに, 決定係数が 0.99 以上の良好な直線性が得られた，標 準溶液 $10 \mu \mathrm{g} \mathrm{mL} \mathrm{mL}^{-1}$ の 3 回の繰り返し測定を実施した結果, 繰り返し精度は, $\gamma$-C9 は $3.2 \%, \gamma$-C10 は $2.0 \%, \delta$-C14 は $3.0 \%$ と良好であった。 これらの成分の定量値は内標準物 質と被検物質の面積比から内標準法により算出した.

\section{$3 \cdot 4$ 添加回収試験}

基材試料として，W/O 型乳化物である油分 $80 \%$ のバ ター, 油分 $70 \%$ 及び $40 \%$ のマーガリン類， $\mathrm{O} / \mathrm{W}$ 型乳化 物である油分 $30 \%$ のクリームを用いて, 添加回収試験を 行った. 各試料を $45{ }^{\circ} \mathrm{C}$ 設定インキュベータに 30 分間静置 


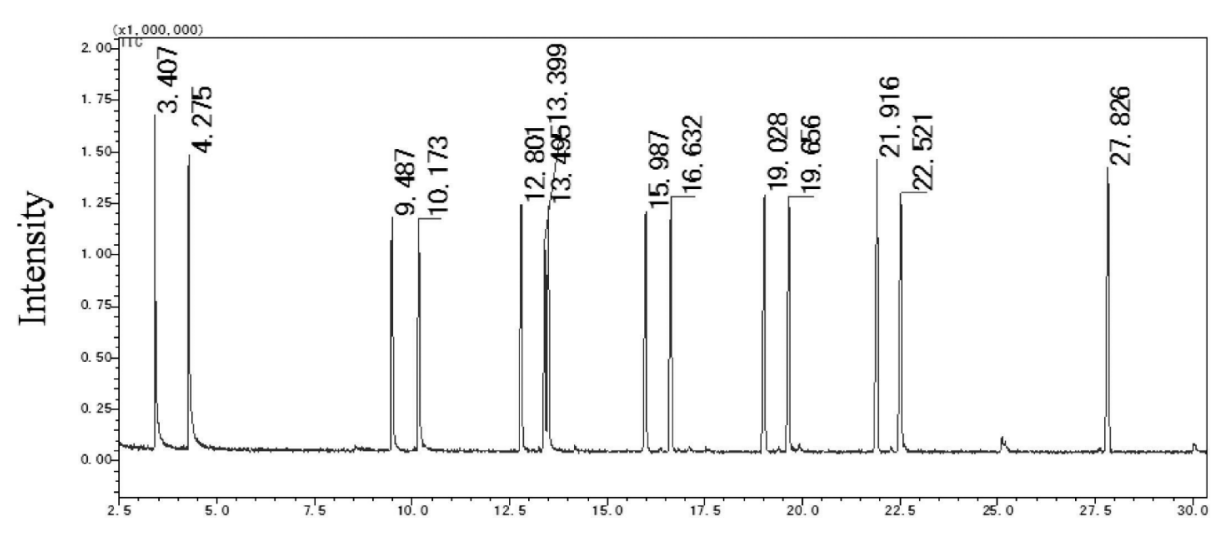

Retention time ( $\mathrm{min})$

$\begin{array}{cl}\text { RT (min) } & \text { Compounds } \\ 3.407 & \gamma \text {-C6 } \\ 4.275 & \delta \text {-C6 } \\ 9.487 & \gamma \text {-C } 8 \\ 10.173 & \delta \text {-C } 8 \\ 12.801 & \gamma \text {-C } 9 \\ 13.399 & \text { Ph2 (IS) } \\ 13.495 & \delta \text {-C9 } \\ 15.987 & \gamma \text {-C10 } \\ 16.632 & \delta \text {-C10 } \\ 19.028 & \gamma \text {-C11 } \\ 19.656 & \delta \text {-C11 } \\ 21.916 & \gamma \text {-C12 } \\ 22.521 & \delta \text {-C12 } \\ 27.826 & \delta \text {-C14 }\end{array}$

Fig. 2 Chromatogram of a standard lactones mixture

Table 2 Recoveries of lactone from spiked sample $(n=3)$

\begin{tabular}{|c|c|c|c|c|c|}
\hline Samples & Fat $\%$ & Lactones & Added $/ \mu \mathrm{g} \mathrm{g}^{-1}$ & Recovery \% & $\mathrm{RSD}^{\text {a) }} \%$ \\
\hline Margarine & 40 & $\begin{array}{c}\gamma \text {-C9 } \\
\gamma \text {-C10 } \\
\delta \text {-C14 }\end{array}$ & $\begin{array}{l}100 \\
100 \\
100\end{array}$ & $\begin{array}{l}121 \\
121 \\
116\end{array}$ & $\begin{array}{r}4.6 \\
2.6 \\
13.6\end{array}$ \\
\hline Margarine & 70 & $\begin{array}{c}\gamma \text {-C9 } \\
\gamma \text {-C10 } \\
\delta \text {-C14 }\end{array}$ & $\begin{array}{l}100 \\
100 \\
100\end{array}$ & $\begin{array}{r}121 \\
116 \\
94\end{array}$ & $\begin{array}{r}1.9 \\
5.9 \\
10.1\end{array}$ \\
\hline Butter & 83 & $\begin{array}{c}\gamma \text {-C9 } \\
\gamma \text {-C10 } \\
\delta \text {-C14 }\end{array}$ & $\begin{array}{l}33.3 \\
33.3 \\
33.3\end{array}$ & $\begin{array}{r}90 \\
103 \\
120\end{array}$ & $\begin{array}{l}2.9 \\
6.3 \\
4.0\end{array}$ \\
\hline Cream (Without $\mathrm{NaCl}$ ) & 30 & $\begin{array}{c}\gamma-\mathrm{C} 9 \\
\gamma \text {-C10 } \\
\delta \text {-C14 }\end{array}$ & $\begin{array}{l}33.3 \\
33.3 \\
33.3\end{array}$ & $\begin{array}{l}95 \\
91 \\
32\end{array}$ & $\begin{array}{l}10.3 \\
12.2 \\
18.1\end{array}$ \\
\hline Cream (Added $1 \% \mathrm{NaCl}$ ) & 30 & $\begin{array}{c}\gamma \text {-C9 } \\
\gamma \text {-C10 } \\
\delta \text {-C14 }\end{array}$ & $\begin{array}{l}33.3 \\
33.3 \\
33.3\end{array}$ & $\begin{array}{l}97 \\
90 \\
87\end{array}$ & $\begin{array}{l}3.9 \\
4.7 \\
7.2\end{array}$ \\
\hline
\end{tabular}

a) relative standard deviation

し, 油水分離が生起しない程度に軟化させた後, $\gamma$-C9, $\gamma$-C10 及び $\delta$-C14 標準品を添加し, 各試料 3 回の前処理及 び測定を実施した。 ラクトン標準品は, バターとクリーム には $33.3 \mu \mathrm{g} \mathrm{g}^{-1}$, マーガリン類には $100.0 \mu \mathrm{g} \mathrm{g}^{-1}$ となる様 に添加した．結果を Table 2 に示す. バターでは, 平均回 収率が 90〜 120\%，相対標準偏差（繰り返し精度\%） 2.9 〜 $6.3 \%$ であった。 マーガリン類では, 平均回収率が 94 〜121\%, 相対標準偏差（繰り返し精度％） 1.9 13.6\% であった. クリームでは, $\mathrm{NaCl}$ を添加しない方法では, 長 鎖構造のラクトン $(\delta$-C14) の回収率が低かったが, 試料調 製時に $\mathrm{NaCl}$ を添加することで, 平均回収率が $87 \sim 97 \%$, 相対標準偏差（繰り返し精度\%) 3.9〜 7.2\% と簡易法とし ては十分な精度にまで改善できた，W/O 型乳化食品であ るバターとマーガリン類では, ヘキサンへの溶解のみによ り試料調製が可能であったが， $\mathrm{O} / \mathrm{W}$ 型乳化食品であるク リームでは, $\mathrm{NaCl}$ の添加により, ラクトン類のヘキサンへ
の移行を促すことが必要であることが分かった、 $\mathrm{NaCl}$ の 添加により，長鎖ラクトン類がへキサン層へ濃縮される機 構は不明であり，解明には分配を考虑した詳細な検討が必 要である。

\section{$3 \cdot 5$ 実試料の繰り返し精度}

実試料として市販バターを用いて，3回の繰り返し測定 を行った，結果を Table 3 に示す，検出された 8.1〜 53 $\mu \mathrm{g} \mathrm{g}^{-1}$ の $\gamma$-ラクトン $(\gamma-\mathrm{C} m, m=12)$ と $\delta$-ラクトン $(\delta$ - $\mathrm{C} n$, $n=10,12,14,16)$ の繰り返し精度は $2.7 \sim 5.4 \%$ であり, 良好であった。クリーム（油分 $42 \%$ ）を用いた試験では, $0.8 \sim 3.8 \mu \mathrm{g} \mathrm{g}^{-1}$ の上記ラクトン類の繰り返し精度は 4.0 〜 $17.3 \%$ であり, バターの結果よりは若干悪い結果であっ た. 
Table 3 Repeatability of GC/MS measurements of butter $(n=3)$

\begin{tabular}{|c|c|c|c|c|c|c|c|}
\hline Lactones & $n$ & \multicolumn{3}{|c|}{ Butter } & \multicolumn{3}{|c|}{ Cream (Fat $42 \%$ ) } \\
\hline$\delta$-C10 & 3 & 22 & 3.1 & 13.9 & 1.8 & 7.6 & 14.0 \\
\hline$\gamma-\mathrm{C} 12$ & 3 & 8.1 & 3.2 & 5.2 & 0.8 & 17.3 & 6.2 \\
\hline$\delta$-C12 & 3 & 41 & 5.4 & 26.2 & 3.5 & 4.0 & 27.1 \\
\hline total & 3 & 155 & - & 100.0 & 13 & - & 100.0 \\
\hline
\end{tabular}

Table $4 \quad \gamma$-lactone and $\delta$-lactone concentration in fat samples

\begin{tabular}{|c|c|c|c|c|c|c|c|c|c|c|c|}
\hline \multirow{4}{*}{ Samples ${ }^{\text {a) }}$} & & & & & & \multicolumn{5}{|c|}{ Concentration $\left(\mu \mathrm{g} \mathrm{g}^{-1}\right)^{\mathrm{b})}$} & \multirow{4}{*}{ Total } \\
\hline & & \multirow[b]{3}{*}{ Fat $(\%)$} & \multirow{2}{*}{\multicolumn{3}{|c|}{$\begin{array}{c}\gamma \text {-lactone }(\gamma-\mathrm{C} m) \\
m\end{array}$}} & \multirow{2}{*}{\multicolumn{5}{|c|}{$\begin{array}{c}\delta \text {-lactone }(\delta \text {-C } n) \\
n\end{array}$}} & \\
\hline & & & & & & & & & & & \\
\hline & & & 9 & 11 & 12 & 10 & 11 & 12 & 14 & 16 & \\
\hline \multirow[t]{3}{*}{ Butter } & $\mathrm{B}-(\mathrm{A})$ & 83 & $<1.0$ & $<1.0$ & 8.1 & 22 & $<1.0$ & 41 & 53 & 32 & 156 \\
\hline & B-(B) & 83 & $<1.0$ & $<1.0$ & 7.6 & 12 & $<1.0$ & 25 & 32 & 24 & 101 \\
\hline & $\mathrm{B}-(\mathrm{C})$ & 83 & $<1.0$ & $<1.0$ & 4.4 & 13 & $<1.0$ & 29 & 34 & 26 & 106 \\
\hline \multirow[t]{7}{*}{ Margarine } & M-(A) & 83 & $<1.0$ & $<1.0$ & $<1.0$ & $<1.0$ & $<1.0$ & $<1.0$ & $<1.0$ & $<1.0$ & - \\
\hline & $\mathrm{M}-(\mathrm{B})$ & 82 & $<1.0$ & $<1.0$ & $<1.0$ & 83 & $<1.0$ & 13 & $<1.0$ & $<1.0$ & 96 \\
\hline & $\mathrm{M}-(\mathrm{C})$ & 23 & 4.7 & 4.8 & $<1.0$ & 19 & 9.1 & 19 & $<1.0$ & $<1.0$ & 57 \\
\hline & $\mathrm{M}-(\mathrm{D})$ & 66 & $<1.0$ & $<1.0$ & $<1.0$ & 5.3 & $<1.0$ & 3.6 & $<1.0$ & $<1.0$ & 8.9 \\
\hline & $\mathrm{M}-(\mathrm{E})$ & 64 & 3.2 & 2.3 & $<1.0$ & 15 & $<1.0$ & $<1.0$ & $<1.0$ & $<1.0$ & 20 \\
\hline & M-(F) & 64 & 20 & $<1.0$ & $<1.0$ & 220 & $<1.0$ & 102 & $<1.0$ & $<1.0$ & 340 \\
\hline & $\mathrm{M}-(\mathrm{G})$ & 82 & $<1.0$ & $<1.0$ & $<1.0$ & 13 & $<1.0$ & 13 & $<1.0$ & $<1.0$ & 27 \\
\hline \multirow[t]{2}{*}{ Cream } & C-(A) & 30 & $<1.0$ & $<1.0$ & 0.4 & 1.0 & $<1.0$ & 1.3 & 1.2 & 1.1 & 4.8 \\
\hline & C-(B) & 42 & $<1.0$ & $<1.0$ & 1.0 & 1.8 & $<1.0$ & 3.5 & 3.8 & 3.0 & 13 \\
\hline
\end{tabular}

a) Food samples were purchased at the market in 2016 . b) $\gamma$-C6, 8, 10, and $\delta$-C6, 8, 9 in all samples were not detected.

\section{$3 \cdot 6$ 市販商品の測定結果}

本法の応用例として, 2016 年時点で市販されていたバ ター (3 品), 生クリーム (2 品), マーガリン類（7 品）の ラクトン含量を測定した。本実験は今回の測定対象物質で あるラクトン類の濃度範囲を明確にすることも目的とす る. 結果を Table 4 に示す. 本分析条件により, $\gamma$-ラクト ン $(\gamma-\mathrm{C} m)$ と $\delta$-ラクトン $(\delta-\mathrm{C} n)$ について, $m, n=6,8$, $9,10,11,12,14,16$ までが分離できた. 本分析では, 試料 中に存在する TG 成分はラクトン類のピークとは重複せ ず, ラクトン溶出後のカラムオーブンの昇温により溶出さ れた. なお, 検量線は $1 \sim 100 \mu \mathrm{g} \mathrm{mL} \mathrm{m}^{-1}$ の濃度の標準物質 を用いて作成し, 決定係数が 0.99 以上の直線性を得ること を確認している. そのため, Table 4 では $1 \mu \mathrm{g} \mathrm{g}^{-1}$ 以上の データのみを示した.

バターのラクトン類としては 5 種類の成分が検出され, 8.1 から $53 \mu \mathrm{g} \mathrm{g}^{-1}$ の範囲で分布し, $\delta$-体が主成分であった. B-(A)，B-(B) は国内産の食塩不使用バターであり，B-(C) は欧州産の発酵食塩不使用バターであるが, $\gamma$-C $12, \delta$-C10, $\delta$-C12， $\delta$-C14， $\delta$-C16 が主要成分であることは共通し，構
成ラクトン類に大きな差がなかった. 油分 $42 \%$ と $30 \%$ の油脂としては乳脂肪のみを含む 2 種類のクリームの分析 では，バターと同じ成分のラクトン類がほぼ近い比率で存 在することが確認できた. 多くの市販のマーガリン類で は, $\delta$-C10， $\delta$-C12 ラクトンの含量が主成分として検出され たが, ラクトン類が検出されないマーガリンも存在したこ とから, マーガリン類のラクトン組成は多様であった.

$$
4 \text { ま と }
$$

バターやマーガリン類の風味にはラクトン類や脂肪酸が 大きく関与しているとされる. ラクトン類の濃度や組成を 精度高く，簡便に測定できる本技術は，乳製品のおいしさ の評価やマーガリン類の配合設計に利用することができ る.今回構築した分析法は, 食品の「おいしさ」に重要な 成分であるラクトン類の簡易定量法として有効な手法であ り利用価值の高い分析法と考える。

\section{文献}

1) 中澤君敏：“マーガリン ショートニング ラード”, 
p. 250 (1979), (光琳).

2) 菅原康文, 大崎和彦, 岩淵久克: 香料, 235,87 (2007).

3) 野口洋介: “牛乳・乳製品の知識”, p. 134, (2000), (幸書房) .

4) D. A. Forss : J. Dairy Sci., 52, 832 (1969).

5) 中島基貴: “香りの技術動向と研究開発”, p. 117 (2004), (フレグランスジャーナル).

6) 大西正展 : 日本食品工学会誌, 15, 199 (2014).

7) 角田 一：日本調理科学会誌, 308, 46 (2013).

8) J. Ruiz, J. Ventanas, R. Cava : J. Agric. Food Chem., 49, 5115 (2001).

9) R. Bassette R : J. Milk Food Technol., 39, 10 (1976).

10）川崎通昭, 中島基貴, 外池光雄 : “におい物質の特
性と分析・評価”, p. 122 (2003), (フレグランス ジャーナル).

11) W. Engel, W. Bahr, P. Schieberle : Euro. Food Res. Technol., 209, 237 (1999).

12) P. Landy, J.-L. Courthaudon, C. Dubois, A. Voilley : J. Agric. Food Chem., 44, 526 (1996).

13) 薄木理一郎, 金田尚志: 油化学, 28, 717 (1979).

14) B. Chongcharoenyanon, N. Yamashita, N. Igura, S. Noma, M. Shimoda: Flavour Fragrance J., 27, 367 (2012).

15) A. J. Taylor: Crit. Rev. Food Sci. Nutr., 36, 765 (1996).

16) 松浦弘明, 藤山勝二, 池内義弘 : 分析化学 (Bunseki Kagaku), 54, 1075 (2005).

\title{
Simple Determination of Lactones in High-fat Food Products by GC/MS
}

\author{
Hiroaki MATSUURA $^{1}$ and Makoto SHIOTA ${ }^{* 1}$ \\ *E-mail : m-shiota@mtf.biglobe.ne.jp \\ ${ }^{1}$ Megmilk Snow Brand Co., Ltd., Milk Science Research Institute, 1-1-1, Minamidai, Kawagoe-shi, Saitama 350- \\ 1165
}

(Received February 20, 2017; Accepted June 2, 2017)

In high-fat products, such as butter, cream, and margarine, simple a determination of lactones that have a sweet aroma was developed using a novel direct-injection GC/MS method. The sample was dissolved in hexane; subsequently, the hexane phase was transferred into an injection port of the GC mounted on a high-temperature-type capillary column with $0.1 \mu \mathrm{m}$ film thickness. After the elution of lactones, the coexistent triacylglycerols in the hexane phase were eliminated from the column by the increasing oven temperature. This method does not consider the distribution ratio between the solvent phase and the water phase, or the vapor phase and adsorbed resin, as is done in conventional methods, such as SPME, because all of the components in the hexane phase are directly transferred into the GC/MS method. The quantity of $\gamma$-lactones and $\delta$-lactones is determined using the selected ion peak area of $\mathrm{m} / \mathrm{z}$ 85 and $m / z$ 99, respectively. The calibration curve displays good linearity in the range of 1.0$100 \mu \mathrm{g} \mathrm{mL} \mathrm{m}^{-1}$. The recovery of the compounds varied from $87 \%$ to $121 \%$, and the reproducibility has been $1.9-13.6 \%$ (R.S.D.). This method was successfully applied to determining the composition of lactones in commercially available butter, cream, and margarines.

Keywords: GC/MS; lactone; butter; cream; margarine; fat; oil. 